\title{
EREBEA
}

Revista de Humanidades

y Ciencias Sociales

NúM. 1 (2011), pp. 231-252

ISSN: 0214-0691

\section{Preaching and Architecture in Tridentine Italy}

\author{
Nirit Ben-Aryeh Debby \\ Ben Gurion University of The Neger
}

REsUmen

El artículo examina los cambios sufridos en el siglo XVI por la forma, función y ubicación de los púlpitos, comparando igualmente la tradición toscana con la de otras regiones de Italia, como el Véneto y la Lombardía. . Le sigue una descripción de las alteraciones promovidas por la Contrareforma Católica, primero en la Toscana y luego - siguiendo las líneas preconizadas por San Carlos Borromeo en su tratado sobre decoración de las iglesias- en los púlpitos gemelos de la catedral de Milán. La estrecha interrelación entre predicación y púlpitos resulta manifiesta cuando los cambios en la teoría y práctica de la predicación afectan al diseño, función y ubicación de los púlpitos.

Palabras Clave

Arquitectura religiosa, Italia, siglo XVI, contrareforma.

Fecha de recepción: 15 de febrero de 2011 Fecha de aceptación: 1 de marzo de 2011

\section{Abstract}

This article examines the changes during the sixteenth century in the form, function and location of pulpits as well as comparing the Tuscan tradition with other regions of Italy such as the Veneto and Lombardy. A review follows of the alterations brought about by the Catholic Reformation, first in Tuscany and thenfollowing the guidelines advocated by San Carlo Borromeo in his treatise on church decoration - in the twin pulpits in Milan cathedral. The close interaction between preaching and pulpits is demonstrated when changes in the theory and practice of preaching affect the design, function and location of pulpits.

KEYWORDS

Religious architecture, Italy, $16^{\text {th }}$ century, counter-reformation. 

In his colorful autobiography, Benvenuto Cellini tells how, with regard to the choir of Santa Maria del Fiori, he was able to regain the good will of his patron, Duke Cosimo de' Medici I:

Then I softened his temper by suggesting that if his most illustrious Excellency did not care to have the door begun, two pulpits had anyhow to be made for the choir, and that these would both of them be considerable works, which would confer glory on his reign; for my part, I was ready to execute a number of bronze basreliefs with appropriate decorations. In this way I brought him round, and he gave me orders to construct the models. ${ }^{1}$

As it turned out, Cellini's pulpits for the choir of Santa Maria del Fiori were not executed (see below). Yet this anecdote shows that pulpits had their importance in the sixteenth century as a source of pride and prestige for patrons, and an artistic challenge for artists.

This article examines the changes during the sixteenth century in the form, function and location of pulpits as well as comparing the Tuscan tradition with other regions of Italy such as the Veneto and Lombardy. It begins with a discussion of pulpit development in Tuscany and other regions during the early sixteenth century, when there seem to have been a variety of forms. A review follows of the alterations brought about by the Catholic Reformation, first in Tuscany and then-- following the guidelines advocated by San Carlo Borromeo in his treatise on church decoration--- in the twin pulpits in Milan cathedral. The close interaction between preaching and pulpits is demonstrated when changes in the theory and practice of preaching affect the design, function and location of pulpits.

\section{Preaching and Pulpits}

This article focuses on an important architectonic and sculptural type in the art of the Italian Renaissance, the pulpit, its aim being to highlight the connections between preacher and pulpit. My main argument is that pulpits should be viewed not only within the milieu of the art historian but in additional contexts; for pulpits are an artistic type that belongs to the world of preaching. A chal-

1 Benvenuto Cellini, The Autobiography of Benvenuto Cellini, trans. by John Addington Symond (New York: The Modern Library, 1965), pp. 454-55. 
lenging issue in the field of sermon studies is the relationship between preaching and art-- in particular, the manner in which preachers used works of art in their sermons as well as the impact of the pulpit itself. One of the oldest forms of church accoutrements, the pulpit has occupied a prominent position in basilicas, cathedrals, and churches since early Christian times. Following the success of the mendicant preachers in medieval and Renaissance Italy, the pulpit became an important item in the church, and developments in the arts led to a new complexity in this traditional genre. In its history, the pulpit has seen many changes in location, form and function. Scholars who concern themselves with pulpits tend to concentrate on the thirteenth and fourteenth centuries, in particular on the exquisite pulpits of the Pisani. ${ }^{2}$ Yet pulpits were of considerable importance in Renaissance art as well. ${ }^{3}$ Though costly, patrons fought for the right to donate them. Such renowned artists as Donatello, Michelozzo, Brunelleschi, Benedetto da Maiano, Antonio and Bernardo Rosselino, and Mino da Fiesole ${ }^{4}$ were recruited to design and construct them, and they were carefully planned to serve the needs and vocation of their client preachers.

2 Numerous studies are dedicated to analyzing the pulpits of the thirteenth and fourteenth centuries, the most recent being Francis Ames-Lewis, Tuscan Marble Carving 1250-1350: Sculpture and Civic Pride (Aldershot: Ashgate, 1997), pp. 67-121; Eloise Marie Angiola, 'Nicola Pisano, Federigo Visconti, and the Classical Style in Pisa', Art Bulletin, 59 (1977), 1-27; Ralph Melcher, Die mittelalterlichen Kanzeln der Toskana (Worms: Wernersche Verlagsgesellschaft, 2000); Piero Morselli and Anita F. Moskowitz, 'The Pistoia Pulpit's Uneven Supports: The Bases for a Hypothesis', Source, 22, no. 2 (2003), 1-9; Timothy Verdon, 'Pulpiti e fonti battesimali in Toscana,' in Il Duomo come libro aperto, ed. by Senio Bruschelli (Siena: Banca Monte dei Paschi, 1998), pp. 137-56; Timothy Verdon, 'Parola, acqua, immagine e spazio: il pulpito e il fonte battesimale', in Il Duomo come libro aperto, pp. 107- 26; Timothy Verdon, 'Verbum caro factum: Teologia, Spiritualità et Iconografia del Pulpito Istoriato', in Pulpiti Medievali Toscani: Storia e Restauri di MicroArchitetture, ed. by Daniela Lamberini (Florence: Olschki, 1999), pp. 17-29. On Romanesque pulpits in Tuscany see Pulpiti Medievali Toscani; Guido Tigler, 'Pulpiti Romanici Toscani: Prime Valutazioni di un Censimento', in Pulpiti Medievali Toscani, pp. 77-94. On the Pisani pulpits see the forthcoming book of Anita F. Moskowitz, Pious Devotion, Pious Diversion: The Pulpits of Nicola and Giovanni Pisano, to be published by Harvey Miller- Brepols Press.

3 On the Renaissance pulpit see Piero Morselli, 'Corpus of Tuscan Pulpits' (unpublished doctoral dissertation, University of Pittsburgh, 1978). Most recently see: Nirit Ben-Aryeh Debby, The Renaissance Pulpit: Art and Preaching in Tuscany 1400-1550 (Turnhout: Brepols, 2007); Nirit BenAryeh Debby, Il Pulpito Toscano tra '300 e '500 (Rome: IPZS, 2009).

4 On Donatello's Prato pulpit see Cesare Guasti, Il pergamo di Donatello per lo Duomo di Prato, (Florence: M. Ricci, 1887); Francesco Guarrieri, Donatello e Michelozzo nel pulpito di Prato, (Florence: Sansoni, 1970); Ronald Lightbown, Donatello and Michelozzo: An Artistic Partnership and its Patrons in the Early Renaissance (London: Harvey Miller, 1980); on Donatello's ambones in Florence's San Lorenzo see Irving Lavin, 'The Sources of Donatello's Pulpits in San Lorenzo', Art Bulletin, 41 (1959), 19-38; Horst W. Janson, Sculpture of Donatello (Princeton: Princeton University Press, 1979); Michael Greenhalgh, Donatello and His Sources (London: Duckworth, 1982); Martha L. Dunkkelman, Donatello's Influence on Italian Renaissance Painting (unpublished doctoral dissertation, New York University, 1976). 
I have adopted an interdisciplinary approach to the topic, combining historical analysis, sermon studies and art history, and examining the pulpit's patronage, location and function as well as its chronological development. I have especially attempted to explore the interrelationships between works of art and sermons, by analysing the manner in which the nature and content of religious preaching shaped the pulpit. Studying the pulpit as a genre rather than as one item within the corpus of works of a given artist has distinct advantages. It enables the scholar to trace the features within this genre that are either traditional or innovative, and it raises a broad range of questions about the function of images, how they come to embody meaning, the reception they meet with and the effect they have.

The pulpit is where the direct influence of the preacher and his vocation is most evident. A raised platform from which the preacher delivers his sermon, the pulpit is a tool used by preachers and it exists within a 'preaching mentality'. The sides of the pulpit are often decorated with reliefs and sculptures meant to be viewed by the sermon's audience; both pulpit and sermon are rhetorical modes working together to convey certain religious and cultural messages. A key issue therefore is, How did the nature and content of religious preaching shape the Renaissance pulpit? This question touches upon a central concern--- namely, the connection between word and image, between the textual and the visual, between sermon literature and pulpits. This is an ancient theme in the study of the arts, where the comparison of poetry and painting, literature and visual art has been a constant topic since antiquity, and one closely connected with the theory of rhetoric. Eloquently formulated by the Roman poet Horace, 'ut pictura poesis' (as is painting, so is poetry), there is a tendency to compare and link word and image ever since. ${ }^{6}$

The pulpit should be seen in the context of a growing interest in the interrelationship of art and preaching. The field of sermon studies, in general, has been flourishing in recent years, culminating in the publication of a conclusive almost one- thousand page volume edited by Beverly Mayne Kienzle, The Sermon, which explores the medieval sermon from various perspectives, across Latin and the different vernaculars. ${ }^{7}$ Important earlier studies include those by Jean

5 About the 'preaching mentality' in Renaissance Florence see Peter Howard, Beyond the Written Word: Preaching and Theology in the Florence of Archbishop Antoninus 1427-1459 (Florence: Olschki, 1995).

6 See Mieke Bal, Reading Rembrandt: Beyond the Word-Image Opposition (Cambridge: Cambridge University Press, 1991); W. J. T. Mitchell, 'Word and Image', in Critical Terms for Art History, ed. by Robert S. Nelson and Richard Shiff (Chicago: University of Chicago Press, 1996); W. J. T. Mitchell, Iconology: Image, Text, Ideology (Chicago: Chicago University Press, 1986); W. J. T. Mitchell, Picture Theory: Essays on Verbal and Visual Representation (Chicago: University of Chicago Press, 1994); Michael Ann Holly, Past Looking: Historical Imagination and the Rhetoric of the Image (Ithaca: Cornell University Press, 1996).

7 See The Sermon, ed. by Beverly Mayne Kienzle (Turnhout: Brepols, 2000). 
Longère, David D'Avray, Nicole Bériou ${ }^{8}$ and, specifically on Italy, the works of Carlo Delcorno and Roberto Rusconi. ${ }^{9}$ An especially stimulating sub- field is the attempt to link preaching and art, verbal and visual culture; Roberto Rusconi has been exploring the iconography of preachers in Italian art. ${ }^{10}$ Another approach is to examine a theme appearing both in sermons and in works of art, as Katherine Jansen has done in her book on the image of Mary Magdalen in the later Middle Ages. ${ }^{11}$ Other scholars have tried to analyse the influence of individual preachers on the visual arts. Michael Baxandall highlighted the significance of

8 The major catalogue of medieval sermons is Johann Baptist Schneyer, Geschichte der katholischen Predigt (Freiburg: Seelsorge, 1968); Repertorium del lateinischen Sermones des Mittelalters für die Zeit von 1150-1350, ed. by Johann Baptist Schneyer, 9 vols (Münster: Aschendorff, 1969-1980). Other catalogues of Franciscan and Dominican preachers are Arthur Zawart, The History of Franciscan Preaching and of Franciscan Preachers 1209-1927 (New York: Wagner, 1928), and Scriptores Ordinis Predicatorum, ed. by Tomasso Kaeppeli (Rome: Istituto storico domenicano, 1970-1975). Essential works are David D'Avray, The Preaching of the Friars: Sermons Diffused from Paris before 1300 (Oxford: Clarendon Press, 1985); Jean Longère, La prédication médiévale (Paris: Ètudes Augustiniennes, 1983); Nicole Bériou and David L. D’Avray, Modern Questions about Medieval Sermons: Essays on Marriage, Death, History and Sanctity (Spoleto: Centro italiano di studi sull'Alto Medioevo, 1994); David d'Avray, Medieval Marriage Sermons: Mass Communication in a Culture without Print (Oxford: Oxford University Press, 2001).

9 On Italian preaching see Carlo Delcorno, La predicazione nell'età comunale (Florence: Sansoni, 1974); Carlo Delcorno, 'L'exemplum nella predicazione medievale in volgare,' in Concetto, storia, miti e immagini, ed. by Vittore Branca (Florence: Sansoni, 1973), pp. 393-408; Carlo Delcorno, Giordano da Pisa e l'antica predicazione volgare (Florence: Olschki, 1975); Carlo Delcorno, Exemplum e letteratura: Fra Medioevo e Rinascimento (Bologna: Il Mulino, 1989); Carlo Delcorno, 'The Language of Preachers: Between Latin and Vernacular,' The Italianist, 15 (1995), pp. 48-64; Roberto Rusconi, Predicazione e vita religiosa nella società italiana da Carlo Magno alla Controriforma (Turin: Loescher, 1981); Roberto Rusconi, 'La predicazione: parole in chiesa, parole in piazza,' in Lo spazio letterario del medioevo, ed. by Guglielmo Cavallo, Claudio Leonardi and Enrico Menestò (Rome: Salerno, 1994), pp. 571-603.

10 See Roberto Rusconi, 'The Preacher Saint In Late Medieval Italian Art', in Preacher, Sermon and Audience in the Middle Ages, ed. by Carolyn Muessig (Leiden: Brill, 2002), pp. 181-202; Roberto Rusconi, 'Women's Sermons at the end of the Middle Ages: Texts from the Blessed and the Images of Saints', in Women Preachers and Prophets through Two Millennia of Christianity, ed. by Beverly Mayne Kienzle and Pamela J. Walker (Berkeley: University of California Press, 1998), pp. 173-195; Roberto Rusconi, 'Giovanni da Capistrano: Iconografia di un predicatore nell'Europa del '400', in Le Venezie Francescane: Predicazione francescana e società veneta nel Quattrocento, Atti del II Convegno internazionale di studi francescani. Padova 26-27-28 marzo 1987, 6 (1989), pp. 31-60; Roberto Rusconi, 'Vicent Ferrer e Pedro de Luna: sull'iconografia di un predicatore fra due obbedienze', in Conciliarismo, stati nazionali, inizi dell'Umanesimo- Atti del convegno xxv storico internazionale Todi, 9-12 ottobre 1988 (Spoleto: Centro italiano di studi sull'Alto Medioevo, 1990), pp. 213-240; Roberto Rusconi, “"Trasse la storia per farne la tavola:” immagini di predicatori degli ordini mendicanti nei secoli XIII e XIV', in La predicazione dei frati dalla metà del '200 alle fine del 300- Atti del XXII convegno internazionale, Assisi, 13-15 ottobre, 1994 (Spoleto: Centro italiano di studi sull'Alto Medioevo, 1995), pp. 405- 450.

11 See Katherine Ludwig Jansen, The Making of the Magdalen: Preaching and Popular Devotion in the Late Middle Ages (Princeton: Princeton University Press, 2000). 
preaching for understanding Italian Renaissance art. It is noteworthy, that he was innovative when paying attention to the connections between the world of preaching and works of art, claiming: 'Sermons were a very important part of the painter's circumstances: preacher and picture were both part of the apparatus of a church, and each took notice of the other.' ${ }^{12}$ Creighton Gilbert has published an anthology of translated passages giving the views of the religious on the arts in the Renaissance. ${ }^{13}$ In a volume edited by Carolyn Muessig on the medieval sermon, Miriam Gill has reflected on the relationship between sermons and medieval wall paintings in England; I contributed a survey of preachers' usage of the visual arts in fifteenth-century Tuscany. ${ }^{14}$ Attention has been paid to the views of Dominican preachers such as: Giovanni Dominici (1356-1419), ${ }^{15}$ Antoninus Pierozzi (1389-1459) ${ }^{16}$ and Girolamo Savonarola (1452-1498), ${ }^{17}$ and Franciscan

12 See Baxandall, Painting and Experience,p. 48.

13 See Italian Art, 1400-1500: Sources and Documents, selected and trans. by Creighton E. Gilbert (Englewood Cliffs NJ: Prentice-Hall, 1980) 145-59. See also the Italian version of the anthology, Creighton E. Gilbert, L'arte del Quattrocento nelle testimonianze contemporanea (Florence: Sansoni, 1988).

14 See Miriam Gill, 'Preaching and Images: Sermons and Wall Paintings in Later Medieval England', in Preacher, Sermon and Audience in the Middle Ages, pp. 155-180; Nirit Ben-Aryeh Debby, 'The Preacher as Goldsmith: Italian Preachers Use of the Visual Arts', in Preacher, Sermon and Audience in the Middle Ages, pp. 127-53.

15 On Dominici's influence on patronage of the arts in the convent of Corpus Domini in Venice see Creighton E. Gilbert, 'Tuscan Observants and Painters in Venice, ca. 1400', in Interpretazioni Veneziani, ed. by David Rosand (Venice: Arsenale, 1984), pp. 109-20. On Dominici's influence on the artistic activity in the convent of San Marco in Florence see William Hood, Fra Angelico at San Marco (New Haven: Yale University Press, 1993), pp. 23-6; on his influence on images found in Santa Maria Novella see Nirit Ben-Aryeh Debby, 'The Images of Saint Birgitta of Sweden in Santa Maria Novella in Florence', Renaissance Studies, 18, no. 4 (2004), 1-18.

16 On Antoninus' perceptions of art see also Frederick Hartt, $A$ History of Italian Renaissance Art (London: Thames and Hudson, 1980); Howard, Beyond the Written Word, pp. 2-3; David Peterson, 'Archbishop Antoninus: Florence and the Church in the Earlier Fifteenth Century' (unpublished doctoral dissertation, Cornell University, 1985). Note also Gilbert's study: Creighton E. Gilbert, 'The Archbishop on the Painters of Florence, 1450', Art Bulletin, 41 (1959), 75-87, giving the views of Archbishop Antoninus (1427-59) on the arts as they appear in his Summa Theologica; for a study examining Antoninus' influence on the image of the Magdalen see Sarah Wilk, 'The Cult of Mary Magdalen in Fifteenth Century Florence and Its Iconography', Studi medievali, 26 (1985), 685-98.

17 On Savonarola and the arts see André Chastel, Art et humanisme à Florence au temps de Laurent le magnifique (Paris: Presses Universitaires de France, 1959), pp. 393-400; Mario Ferrara, Prediche e scritti (Florence: Olschki, 1930), pp. 45-72; Gustave Gruyer, Les illustrations des écrits de J. Savonarola publiés en Italie au XV e XVI siécles et les paroles de Savonarole sur l'art (Paris: Librairie de Firmin- Didot, 1879); Marcia B. Hall, 'Savonarola's Preaching and the Patronage of Art', in Christianity and the Renaissance, pp. 493-522; Stanley Meltzoff, Botticelli, Signorelli and Savonarola: Theologica Poetica and Painting from Boccaccio to Poliziano (Florence: Olschki, 1987); Ronald Steinberg, Fra Girolamo Savonarola, Florentine Art and Renaissance Historiograph (Athens: Ohio University Press, 1977). 
preachers such as Bernardino da Siena (1380-1444), ${ }^{18}$ and to the impact of their preaching on the visual arts.

A challenging task is to directly address the connections between verbal and visual rhetoric. In The Web of Images: Vernacular Preaching from Its Origins to St. Bernardino da Siena, Lina Bolzoni has studied the links between the Renaissance art of memory and the strategies of medieval preaching, exploring the relation between several works of art to the rhetoric of preaching. She begins her discussion with an analysis of the famous series of frescoes in the Pisan cemetery known as the Trionfo della morte, which was frequently used as a point of reference by the medieval preachers. Bolzoni describes the spectacular imagery of death and damnation in these frescoes, imagery that appears also in the vernacular of later medieval preachers such as Giordano da Pisa. The author suggests that such images as the Tree of Knowledge, the Seven Deadly Sins, and the Tower of Wisdom were used as part of a long-established repertory of Christian imagery that combined with medieval sermons to lead the mind of the believer away from the evils of the world and towards a mystical vision of God. These images were recomposed again and again, in different orders and with varying verbal accompaniment, in a flexible rhetorical exercise that drew great crowds into the churches and squares of Italy. ${ }^{19}$

A recent somewhat different attempt to draw the verbal and visual together, dealing with an earlier period and in a French context, is Stephen Murray, $A$ Gothic Sermon: Making Contract with the Mother of God, Saint Mary of Amiens. In this book, Murphy highlights and compares the structure of the vernacular sermon with the sculptural program of Notre Dame Cathedral in mid-thirteenth century Amiens. Murray points out that sermons and sculptures alike direct attention to the Virgin Mary; the three paths of salvation set out by the preacher--- repentance and good works, the church's clergy and sacraments, and the Virgin Mary--- correspond to the themes evoked in the three main portals of the cathedral's west façade. Murray connects the tools of rhetoric to those of carving and discusses parallels between the verbal, performative world of the sermon and the visual program of the cathedral. Murray's effort to explore the link between

18 On Bernardino da Siena and the visual arts see Enzo Carli, 'Luoghi ed opere d'arte senesi nelle prediche di Bernardino del 1427', in Bernardino predicatore nella società del suo tempo: Atti del Convegno (Todi: L'Accademia Tudertina, 1976), pp. 155-82; Nirit Ben-Aryeh Debby, 'War and Peace: The Description of Ambrogio Lorenzetti's Frescoes in St. Bernardino's Sermons in Siena 1425', Renaissance Studies, 15, no. 3 (2001), 272-86.

19 See Lina Bolzoni, La rete delle immagini: Predicazione in volgare dalla origini a Bernardino da Siena (Turin: Einaudi, 2002); for the English version see Lina Bolzoni, The Web of Images: Vernacular Preaching from Its Origins to St. Bernardino da Siena, trans. by Carole Preston and Lisa Chien (Aldershot: Ashgate, 2004). See also her book on the Renaissance art of memory, considered in a literary context: Lina Bolzoni, La stanza della memoria: Modelli letterari e iconografici nell'età della stampa (Turin: Einaudi, 1995); and the English version, Lina Bolzoni, The Gallery of Memory, trans. by Jeremy Parzen (Toronto: University of Toronto Press, 2001). 
the visual and the verbal is, I hope, carried on in this essay with regard to pulpits. ${ }^{20}$ For against the backdrop of this rich scholarship the pulpit itself, as a monument linked directly with sermons and preaching, has been largely ignored.

\section{The Tuscan Pulpit in the First Half of the Sixteenth Century}

In the early sixteenth century, most pulpits in Tuscany continued the fifteenth-century tradition and maintained the characteristics of the previous era. According to Morselli's catalogue, the pulpits in the first decades of the sixteenth century were devoid of figural representations, were usually cylindrical or polygonal in shape and repeated the decorative motifs found in earlier pulpits such as the pulpit in San Gimignano's Church of Sant'Agostino (inspired by the da Maiano scheme in Santa Croce) or the pulpit in Sant'Andrea in Brozzi. ${ }^{21}$

Sketches made by Michelangelo around 1518 for an ambo for the choir of Florence's Cathedral of Santa Maria del Fiore provide intriguing suggestions for a new form of pulpit. These preliminary drawings are preserved in Oxford's Ashmolean Museum and in the British Museum. Morselli believes that Nicola Pisano's pulpit in the Pisa Baptistery was the source that inspired Michelangelo's plans for a new concept of a tall, free standing octagonal structure with large niches intended as an ambo for Florence's cathedral. Although the monuments differ in their ornaments and decorations, they are similar in their architectural structure and disposition. ${ }^{22}$

An important development in the sixteenth century, evidenced by Donatello's San Lorenzo pulpits was the revival of double ambones for reading the Gospels and the Epistles. ${ }^{23} \mathrm{~A}$ plan for two ambones for the choir of Florence's cathedral was suggested by Benvenuto Cellini around 1549. These ambones, commissioned by Cosimo de' Medici I, were supposed to be richly decorated with narrative reliefs. Cellini presented several models to Cosimo and had a clash with his patron: while Cosimo favoured a rectangular shape (as in San Lorenzo), Cellini advocated the octagonal form as better suited to the octagonal shape of the choir. Here is Cellini's story of the models:

Accordingly I set to work on several models, and bestowed immense pains on them. Among these there was one with eight panels, carried out with far more science than the rest, and which seemed to me more fitted for the purpose.

20 See Stephen Murray, A Gothic sermon: Making Contract with the Mother of God, Saint Mary of Amiens (Berkeley: University of California Press, 2004).

21 Morselli, 'Corpus of Tuscan Pulpits,' pp. 19-20.

22 Morselli, Piero. 'A Project by Michelangelo for the Ambo(s) of Santa Maria del Fiore, Florence'.

23 See Marchita Bradford Mauck, 'Ambo', in The Dictionary of Art, I, pp. 764-65. 
Having taken them several times to the palace, his Excellency sent word by Messer Cesare, the keeper of his wardrobe that I should leave them there. After the Duke had inspected them, I perceived that he had selected the least beautiful. One day he sent for me, and during our conversation about the models, I gave many reasons why the octagonal pulpit would be far more convenient for its destined uses, and would produce a much finer effect.

He answered that he wished me to make it square, because he liked that form better; and thus he went on conversing for some time very pleasantly. I meanwhile lost no opportunity of saying everything I could in the interests of art. Now whether the Duke knew that I had spoken the truth, or whether he wanted to have his own way, a long time passed before I heard anything more about it. ${ }^{24}$

This dispute between patron and artist probably resulted in only the preliminary stage of the project being built; while the ambones were to be executed in bronze and marble, only their wooden skeletons were prepared. Another, earlier, option, as indicated by Vasari, was that of Baccio Bandinelli, Cellini's bitter enemy, with the intention of building two ambones for Florence's cathedral. This plan was never realised, again because of the lack of interest of the patron, Cosimo de Medici I. ${ }^{25}$

The Tuscan pulpit as it developed during the fifteenth century was widely influential in the early decades of the sixteenth century. Especially dominant was Benedetto da Maiano's pulpit, which inspired the form and design of several others, especially in southern Germany. Pulpits in Spain and Portugal were also influenced by Italian examples. The pulpit of Coimbra Cathedral (1520s), for example, attributed to João de Ruão, is derived from that in Florence's Santa Croce. Its polygonal casket is supported by richly decorated columns joined by rounded arches that form niches for sculptures. The corners are accentuated by Gothic pilasters, with canopied niches for additional sculpture. The stairway is decorated with putti and wild animals and terminates in a dragon at the base. Benedetto da Maiano's influence is also evident in pulpits created in the Netherlands. The pulpit (1548) in the Oude Kerk, Delft, has a hexagonal casket with panels enclosed by Corinthian columns; round- headed niches in low relief contain representations of the apostles and the scene of baptism, and the base below the casket is decorated with satyrs and scroll reliefs. Individual elements typical of the Italian Renaissance pulpit--- such as the sound board with the depiction of the holy dove above the head of the preacher featured in Santa Maria Novella's pulpit became common in pulpits constructed in Protestant countries. Yet while the early- sixteenth-century 
pulpit tradition preserved the forms of the fifteenth century, the increasing turmoil of the later sixteenth century brought about a transformation in pulpit design. ${ }^{26}$

\section{Church Interiors in the Second Half of the Sixteenth Century}

Urgent calls for the reform of church plans were made during the Catholic Reformation, beginning in the 1530s, continuing and gathering momentum as the century proceeded. The decrees of the Council of Trent stressed the importance of active lay participation in the Mass. Consequently the rood screens and choir enclosures existing in many monastic churches were no longer suitable, since they blocked the laymen's view of the high altar, highlighted the separation between clergy and laity and promoted hierarchy instead of participation. Gradually the problematic rood screens and the ambones attached to them were removed. The religious ideology underlining this architectural transformation was the elimination of the division between main altar and laity so as to enable believers to take a more active part in the mass. ${ }^{27}$

In Florence, for example, the reform was initiated in various churches, among them the Carmine, Ognissanti and Santa Trinità. In the great mendicant churches, Santa Croce and Santa Maria Novella, significant alterations were made by Giorgio Vasari, commissioned by Cosimo de' Medici I. Vasari might have been in favour of removing the roodscreens also for aesthetic reasons, so as to create a unity of space in the church in accordance with Renaissance architectural concepts. The rood screens with their ambones were removed from churches, new choirs were built behind the high altar and the fifteenth- century pulpits located in the lower nave became the centre of preaching activities. ${ }^{28}$ In other churches in Italy, such as Santo Stefano in Prato and the Duomo of Arezzo (Fig. 1), similar steps were taken. The elimination of roodscreens was gradually carried out in Italian churches from the sixteenth century through the seventeenth. In Venice's Dominican church, Santi Giovanni e Paolo, for example, the choir screen was destroyed in $1682 .{ }^{29}$

26 Kockelbergh, 'Pulpit,' in The Dictionary of Art, XXV, pp. 724-28.

27 See Hall, Renovation and Counter-Reformation, pp. 1-15; Sible de Blaauw, 'Innovazioni nello spazio di culto fra basso Medioevo e Cinquecento: la perdita dell'orientamento liturgico e la liberazione della navata', in Lo spazio e il culto. Relazioni tra edificio ecclesiale e uso liturgico nel XVe XVI secolo: Atti delle Giornate di Studio (Firenze, 27-28 marzo 2003), ed. by Jörg Stabenow (Venice: Marsilio, 2006), pp. 25-52; Riccardo Pacciani, 'Il coro contesto. Rituali civici, movimenti d'osservanza, privatizzazioni nell'area presbiteriale di chiese fiorentine del Quattrocento,' in Lo spazio e il culto, pp. 127-52.

28 See Hall, Renovation and Counter-Reformation, pp. 12-15; Rudolf Wittkower, Architectural Principles in the Age of Humanism (London: Tiranti, 1967).

29 See Deborah Howard, The Architectural History of Venice (New Haven and London: Yale University Press, 2002), pp. 81-85. 
Two exceptional cases in Italy where the rood screens remain intact to this day are Modena's cathedral (Fig. 3) and Venice's Santa Maria Gloriosa dei' Frari. The former is a unique case of an ambo set on a rood screen, preserved since the Middle Ages, in addition to a preaching pulpit located in the lower nave. The halfcircular ambo depicts the doctors of the Church--- Jerome, Ambrose, Augustine and Gregory--- and the symbols of the evangelists, as well as a scene of Christ enthroned with a book. It was probably used for the reading of the Gospels and the Epistles. Besides the ambo on the roodscreen, there is also a pulpit inserted on a pilaster on the southern side of the church that was constructed in 1322 and used mainly for preaching; it is situated in the middle of the nave, easily accessible to the congregation. ${ }^{30}$ In Venice, an interesting example is the choir screen in Santa Maria Gloriosa dei Frari built in a late Gothic style, probably by Pietro Lombardo and his workshop, with two ambones; it was begun in 1460 and completed by 1475. The two ambones were mainly used for liturgical services. ${ }^{31}$

The aim of papal policy during the Catholic Reformation was to regain the domination and authority the Church had enjoyed during the Middle Ages, when preaching was viewed as a major tool to establish ecclesiastical hegemony. In the decree Super lectione et praedicatione of the Council of Trent (1546), much attention was paid to preaching; it was equated with the reading of the Gospels and the Epistles and was defined as one of the central missions of the bishop. The new religious orders such as the Barnabites (1530), the Capuchins (1529) and especially the Jesuits (1540) placed a renewed emphasis on preaching. ${ }^{32}$ The houses of worship built by these new orders were specifically designed as preaching churches and stressed the importance of providing large open spaces for the congregation. A typical example was Rome's Gesù church, the mother church of the Jesuit Order planned by Jacopo Vignola; it was begun in 1568 and consecrated in 1584. With its broad single nave, short transept and impressive dome this church was ideally suited for preaching from the pulpit to great numbers of people. It established the type of large congregational church that was to dominate the late sixteenth and early seventeenth centuries. Additional houses of worship built in

30 On Modena see Arturo Carlo Quintavalle, Il Duomo di Modena (Florence: Sansoni, 1965); Moskowitz, Italian Gothic Sculpture, p. 289.

31 Piero Angelo and Marco Caccin, La Basilique de S. Maria Gloriosa des Frari à Venise (Venice: Zanipolo, 1964); see also Ralph Lieberman, Renaissance Architecture in Venice 1450-1540 (London: Müller, 1982); John McAndrew, Venetian Architecture of the Early Renaissance (Cambridge MA: MIT Press, 1980), pp. 55-57.

32 See Blunt Anthony, Artistic Theory in Italy 1400-1600 (Oxford: Oxford University Press, 1962), pp. 102-104; Louis Hautecoeur, 'Le concile de Trente et l'art', in Il concilio di Trento e la riforma tridentina: Atti del convegno storico internazionale (Rome: Herder, 1965), pp. 345-62; Emile Mâle, L'art religieux après le Concile de Trent (Paris: Colin, 1932); John W. O’Malley, The First Jesuits (Cambridge MA: Harvard University Press, 1993); John W. O’ Malley, Trent and All That: Renaming Catholicism in the Early Modern Era (Cambridge MA: Harvard University Press, 2000). 
Rome and used by the new orders, which attached great value to preaching, were S. Maria in Vallicella for St. Philip Neri's order in 1575, S. Andrea della Valle for the Theatines and a second vast Jesuit church, S. Ignazio, begun in 1626. The canonisation of San Carlo Borromeo in 1610 was followed by the dedication to him of no less than three additional churches in Rome: the very large S. Carlo al Corso, S. Carlo ai Catinari, built for the Barnabites, and the small S. Carlo alle Quattro Fontane, which was later replaced by Borromini's structure. ${ }^{33}$

Accompanying the continuing importance of preaching was a new desire for visibility of the pulpit, in both the Roman Catholic and the Protestant churches. In the latter, the pulpit--- reduced to a cabinet- like piece of furniture and only sparsely decorated with ornamental motifs--- often became the focal point of worship, especially in Calvinist churches, the main centres of development in the late sixteenth century and beginning of the seventeenth being in Germany and Flanders. In the Catholic church, in contrast, reformers continued to emphasise the value of sacred images as a spur to piety and a means of salvation, and in the Council of Trent religious art was recognised as a valuable tool of propaganda. Accordingly, the iconography of the pulpit was sometimes used to highlight the triumph of the Church over heresy through the power of oratory, a telling example being the twin pulpits in Milan's cathedral (Fig. 4). ${ }^{34}$

Changes in theological ideals brought about transformations in religious furniture, and the Renaissance pulpit was viewed as no longer suited to the new demands. The individual who had proposed a new conception of the pulpit was San Carlo Borromeo (1538-1584), a high functionary of the church, a patron, collector, religious reformer and writer, and one of the most influential figures of the Catholic Reformation; he had a profound effect on the theory and practice of preaching as well as on Italian art and architecture.

\section{San Carlo Borromeo: Pulpits and Preaching in Tridentine Italy}

Carlo Borromeo was created a cardinal in 1560 and moved to Rome; there, as secretary of state to the pope, he played a significant role in formulating the decrees of the Council of Trent. In Rome, he explored early Christian remains, and his interest in the early Church--- a response to Protestant attacks--- informed his later writings. He was appointed archbishop of Milan in 1563 and filled this position until $1584{ }^{35}$

33 See James S. Ackerman, 'The Gesù in the Light of Contemporary Church Design', in $B a-$ roque Art: the Jesuit Contribution, ed. by Rudolf Wittkower and Irma Jaffe (New York: Fordham University Press, 1972), pp. 15-28; Rudolf Wittkower, Art and Architecture in Italy 1600-1750, rev. by Joseph Connors and Jennifer Montagu (New Haven: Yale University Press, 1999), pp. 15-17.

34 Kockelbergh,'Pulpit,' p. 725.

35 On Carlo Borromeo see San Carlo Borromeo: Catholic Reform and Ecclesiastical Politics in the Second Half of the Sixteenth Century, ed. by John M. Headley and John B. Tomaro (Washington 
Borromeo holds an important place in the history of preaching. He himself was an active preacher who stressed the centrality of preaching, having written treatises on the technique of preaching and the importance of sacred eloquence and ecclesiastical rhetoric. He viewed preaching as the mission of the bishop and set up a new model of the preacher in an influential tract on the principles of sacred oratory, Instructiones praedicationis verbi Dei (1576). In it he pinpointed sins, virtues and the sacraments as the essential ingredients of sermons. The preacher is required to be a virtuous person, and Borromeo prescribed a life-style for the preacher that set him off from the laity. In his role as archbishop of Milan, Borromeo attempted to bring to the city the most successful preachers. He distinguished between two types of preachers: the tenured bishops, who carried the major burden of responsibility, and the itinerant preachers. In a letter to Gabriele Paleotti, bishop of Bologna, he admitted that he greatly preferred a tenured preacher, attached to and controlled by the bishop, to the more independent, temporary preachers, who were usually members of the religious orders. Borromeo himself was a highly influential preacher who, in his role as archbishop of Milan, sometimes preached as often as three or four times a day. His sermons on the doctrines of Creation and Redemption were frequently innovative, manifesting an optimistic view of the spiritual potential of humankind, created by God and redeemed by Christ. He departed from the scholastic and mendicant form of preaching typical of the preceding centuries, choosing instead a form centred on the biblical texts. Many of his sermons might be described as homilies, in that they were loose commentaries on a verse or passage from the Scriptures and were characterised by a desire to return to the simpler style of the Church Fathers and to patristic methodology. ${ }^{36}$

Deeply influenced by the decrees of the Council of Trent, Borromeo believed that religious art should be clear and direct, that it should educate the beholders and move them to penance. Other views Borromeo promoted were that collaboration between priests and artists was important and that the content of a work of art should be dictated by theologians. The latter perception was advocated by others too, among them Paleotti: 'The art of making images', he argued, 'is among the noblest arts if it is directed by Christian discipline.' In his influential Instructiones fabricae et supellectilis ecclesiasticae libri duo (begun after 1572 and completed in Milan in 1577), Borromeo set out his proposals for the reform of church architecture and decoration. The first section, comprising thirty- three chapters, related to the building and its interior; the second, highly detailed, to ecclesiastical furnishings.

DC: The Folger Shakespeare Library, 1988); Carlo Borromeo e l'opera della Grande Riforma, ed. by Franco Buzzi and Danilo Zardin (Milan: Silvana Editoriale, 1997); Richard V. Schofield, "'Tu es diaboli ianua”. Carlo Borromeo, misoginia e architettura', in Lo spazio e il culto, pp. 281-352.

36 John W. O’Malley, 'Saint Carlo Borromeo and the Praecipuum Episcoporum Munus: His Place in the History of Preaching,' in O'Malley, Religious Culture, pp. 140-57. 
Borromeo discussed the symbolic aspects of church buildings, his aim being to fuse this symbolism with liturgical practicalities so as to produce buildings of simple design. The main principle he proposed was that to affect the congregation the church itself and the services held in it must be as dignified and impressive as possible. In his prologue to the Instructiones, he praised the ancient tradition of ecclesiastical grandeur and demanded that priests and architects make a joint effort to maintain it. He recommended that the church be built in a prominent position, if possible on a hill, and have stairs leading up to it, while its façade should be decorated with figures of the saints and be elaborately ornamented.

Within the church, the high altar should be raised, to give it greater emphasis, and be part of a spacious chancel. The transept should include chapels with big altars for special services. Rich vestments should be worn during religious ceremonies, and the windows of the church should be filled with white glass to enable light to penetrate. Everything had to be done properly: without vanity, and excluding anything secular or pagan. The model was the early church and its traditions; thus the shape of the church had to be in the form of a Latin cross rather than the Greek cross proposed by Renaissance theorists. Even details had to be in line with ancient Christian tradition: the doors had to be square-headed, not arched; because the former kind were found in early Christian basilicas whereas the latter were a pagan design. Ecclesiastical considerations should predominate and purely artistic considerations be allowed only in matters that were ecclesiastically neutral. ${ }^{37}$

Borromeo's architectural principles were highly influential; instrumental in implementing them was Pellegrino Tibaldi, who designed buildings in Milan and Pavia from 1564 to 1582 and whose Discorso dell'architettura was strongly influenced by Borromeo. Buildings designed by Tibaldi and encompassing the models of Borromeo include the churches of San Carlo al Lazzaretto (1576-92), San Sebastiano (1577) and the Jesuit church San Fedele in Milan (Fig. 5). Among the other architects influenced by Borromeo were Martino Bassi, who reconstructed the ancient church of San Lorenzo, and Andrea Palladio, who was responsible for Il Redentore in Venice. The latter church, which was devoid of any superfluous ornamentation and had a choir separate from the presbytary, exemplified Borromeo's call for simplicity. ${ }^{38}$

In his treatise, Borromeo specified the functions, form and location of pulpits and ambones in his ideal church: ${ }^{39}$

37 Blunt, Artistic Theory, pp. 127-32; Cecilia Voelker, 'Borromeo's Influence on Sacred Art and Architecture,' in San Carlo Borromeo: Catholic Reform, pp. 172-87.

38 See Antonio Scotti, 'Architettura e riforma cattolica nella Milano di Carlo Borromeo,' L'arte, 5 (1972), 54-90; Antonio Scotti, 'Larchitettura religiosa di Pellegrino Tibaldi,' Bollettino del Centro Internazionale di Storia dell'Architettura Andrea Palladio, 19 (1977), 221-50.

39 See Paola Barocchi, Trattati d'arte del Cinquecento fra Manierismo e Controriforma, 3 vols 
On the Ambones and the Pulpit

The most noteworthy churches and all cathedrals must have ambones decorated with marble and rich ornaments in the same manner as those that once existed in antiquity and still can be seen in Rome. When of bronze, they should be decorated with historiated reliefs of sacred images.

On the Two Ambones

If the church is large it is possible to have two ambones. On solemn occasions the Gospel will be read from the taller of the two. The other, which will serve for the reading of the Epistles and the recitation of the Holy Scriptures, should be lower.

On the Ambo

It is permitted to build a single ambo like those which can be seen in many churches. It will serve for the reading of the Gospels and of the Epistles but, in any case, the place from which the Gospels will be read must be higher than that from which the Epistles will be read. The lower level of the ambo, or another level lower than the ambo itself, will be reserved for the choir and the clerics so that, according to ancient tradition, they may sing, for solemn festivities or on certain days, predetermined chants between the reading of the Gospels and the reading of the Epistles. When possible, two flights of stairs will be built for the ambo, one toward the east, to ascend, the other toward the west, to descend.

On the Location of the Ambo

If only one ambo is to be built for a church it will be placed on the Gospels side. If two are built, the one that will hold the Epistles will be placed on the Epistles side, the other, for the Gospels, will be built on the Gospels side, and the deacon, when reading the Gospels, will face the south, where the men are standing. The ambones should be built of marble or stone and must be decorated in relief with religious subjects. Brick construction is also permitted provided that the surface is covered by marble slabs or with elegantly sculpted stone or gilt- bronze as may be seen today in many churches.

Borromeo's instructions regarding pulpits demonstrate the general tone set by the Council of Trent indicating sympathy for early Christian liturgical traditions and manifesting a renewed interest in the form of the ambo. Borromeo points out examples of ambones to follow: those in the Roman basilicas such as San Lorenzo fuori le mura, Santa Maria in Cosmedin and San Clemente, where the two ambones face each other midway along the sides of the schuola cantorum. In San Clemente, the ambo on the right was intended for the reading of the Epistles and

(Bari: Laterza, 1960- 62), III, pp. 62-63. (Carlo Borromeo, Instructiones fabricae et supellectilis eccelesiasticae ); for the English translation see Morselli, 'Corpus of Tuscan Pulpits', pp. 23-24. 
included fragments of the sixth- century ambo from the lower basilica. The ambo on the left was reserved for the reading of the Gospels and included two sets of stairs constructed in the tradition of the sixth- century ambones of Constantinople and Ravenna. ${ }^{40}$ On the whole, then, the detailed instructions regarding the pulpits and ambones are oriented towards Roman models.

Borromeo's ideals regarding the form and function of pulpits are best exemplified in the twin ambones in Milan's cathedral. These unique monuments have recently been the subject of an important study by Jörg Stabenow, who discussed their form, location and function in relation to Borromeo's theories. The two ambones were commissioned by Borromeo when he was archbishop of Milan in 1580, and were designed and built by Pellergrino Tibaldi. ${ }^{41}$ Before turning to these two ambones, Stabenow mentions the example of Milan's Jesuit Church of San Fedele, planned by Pellegrino Tibaldi, where the pulpit, installed in 1581, is situated in the second bay on he left-hand side of the church and is part of the wall, accessible by a hidden staircase. This arrangment follows that of pulpits in earlier mendicant churches--- such as Florence's Santa Maria Novella and Santa Croce--- and highlights the distinction between Mass and preaching.

The installation of the two pulpits was part of a general plan of refurnishing of the cathedral, planned by Borromeo and executed by Pellegrino Tibaldi in 1567. The interior of the cathedral was transformed by Tibaldi's reconstruction of the crypt, the high altar and the choir. The main altar, for which Tibaldi designed a domed and columned tiburio supported by sculpted angels, is raised by a flight of steps, which gives it the illusion of greater height; it is set above a circular crypt (the scurolo), in which the central ring of columns and surrounding ambulatory recall early Christian structures. The choir, containing two tiers of lavishly carved fixed stalls, is bounded by two great carved wooden organ cases and an enclosing wall decorated with marble reliefs. ${ }^{42}$

The two pulpits were installed as part of the restorations. Documents attest that the left pulpit was begun in 1580 and completed by 1584, while the right was begun in 1584 and completed by 1599. According to Stabenow, the situation regarding the use of the two pulpits was complex. In a guide to the church compiled by the Jesuit Paolo Morigia in 1597, the functions of the two pulpits are defined as follows: 'Uno de quali serve per la predica dell'illustrissimo archivescovo, e per cantarvil'epistola, et il Vengelio et per altre ceremonie; e l'altro serve per gli altri predicatori.' This testament clarifies that the pulpit on the left was used by the archbishop for either preaching or reading the Scriptures, while

40 See Emile Mâle, The Early Churches of Rome, trans. David Buxton (London: Benn, 1960); Guglielmo Matthiae, San Lorenzo fuori le mura (Rome: Edizioni Roma, 1959).

41 Jörg Stabenow, 'Il duplice pulpito di Carlo Borromeo nel Duomo di Milano: tradizione e invenzione,' in Lo spazio e il culto, pp. 227-81.

42 Scotti, 'Architettura e riforma cattolica'. 
the one on the right was used by less important preachers. The distinction between the two pulpits was not based on the material read from them but on the rank of the clerics using them.

A comparison of Borromeo's theoretical instructions with the pulpits in the cathedral reveals some differences. Borromeo used the term 'ambones' to refer to more prestigious marble permanent structures, and the term 'pulpit' for wooden, often movable structures found in lesser churches--- but in either case they were used both for preaching and for reading the Gospels and the Epistles. He underlined that the two ambones should not be equal in height; the one intended for the reading of the Gospels had to be higher than the one intended for the reading of the Epistles, and if there was only one ambo in the church, it should include two places of different height for the diverse readings.

The twin ambones in Milan's cathedral correspond with the demand that the most important churches should posses two ambones. Yet the two ambones are identical in height and thus contradict Borromeo's instructions. (Perhaps another source of influence for the actual shape of these pulpits were the twin symmetrical ambones found in the medieval churches of Venice such as San Marco). ${ }_{43}$ Contrary to Borromeo's mandate, the twin pulpits serve merely to emphasise the discrepancy in prestige between the archbishop and the itinerant preachers. The position of the ambones, in the vicinity of the high altar, is in line with Borromeo's general instruction that the ambo should be located near the altar, at the crossing. This location gives expression to the demand that the priest should engage in preaching during mass and reflects the centrality of preaching in the reformed church. In a sense, Borromeo wanted preaching to become a part of the liturgy. The location of the twin ambones in Milan's cathedral would inspire other examples, as in the Barnebite church of Sant'Alessandro in Milan, where the pulpit is placed at the centre of a centralized plan. ${ }^{44}$ On the whole, Stabenow concludes, while most pulpits constructed in the Catholic Reformation retained their place in the lower nave, in the case of the twin pulpits in Milan an attempt was made to transfer the pulpit to a central position near the altar and to bring together preaching and the mass.

\section{Conclusions}

An examination of pulpits in the sixteenth century shows two main lines of development: continuity and innovation. The forms as well as the location in the lower nave were often retained in the sixteenth century, as was the revival

43 On Venetian churches see Howard, The Architectural History, pp. 17-20, 81-85; Otto Demus, The Church of San Marco in Venice: History, Architecture, Sculpture (Washington DC: The Dumbarton Oaks Papers, 1960).

44 Stabenow, Jörg, 'La chiesa di Sant'Alessandro a Milano: riflessione liturgica e ricerca spaziale intorno al 1600,' Annali di architettura, 14 (2002), 215-29. 
of the double ambones. Pulpits continued to be the casus belli between artists and patrons, as in the case of Cellini and Cosimo. From another perspective, the sixteenth century witnessed changes brought about by the spirit of reform and transformations regarding liturgy and preaching during the Catholic Reformation. In most churches, the rood screens with their ambones were removed, making the preaching pulpits in the lower nave the centre of preaching activities in the church. Leading refomers such as San Carlo Borromeo formulated a new functional definition of the pulpit based on the early Church, and they largely carried out their ideals in practice, as in the twin ambones in Milan Cathedral. With the affinity between preaching and pulpits maintained in the sixteenth century, changes in preaching habits and the attempt to include preaching as part of the liturgy brought about a change in the pulpit's function and location, best exemplified in Milan Cathedral. 

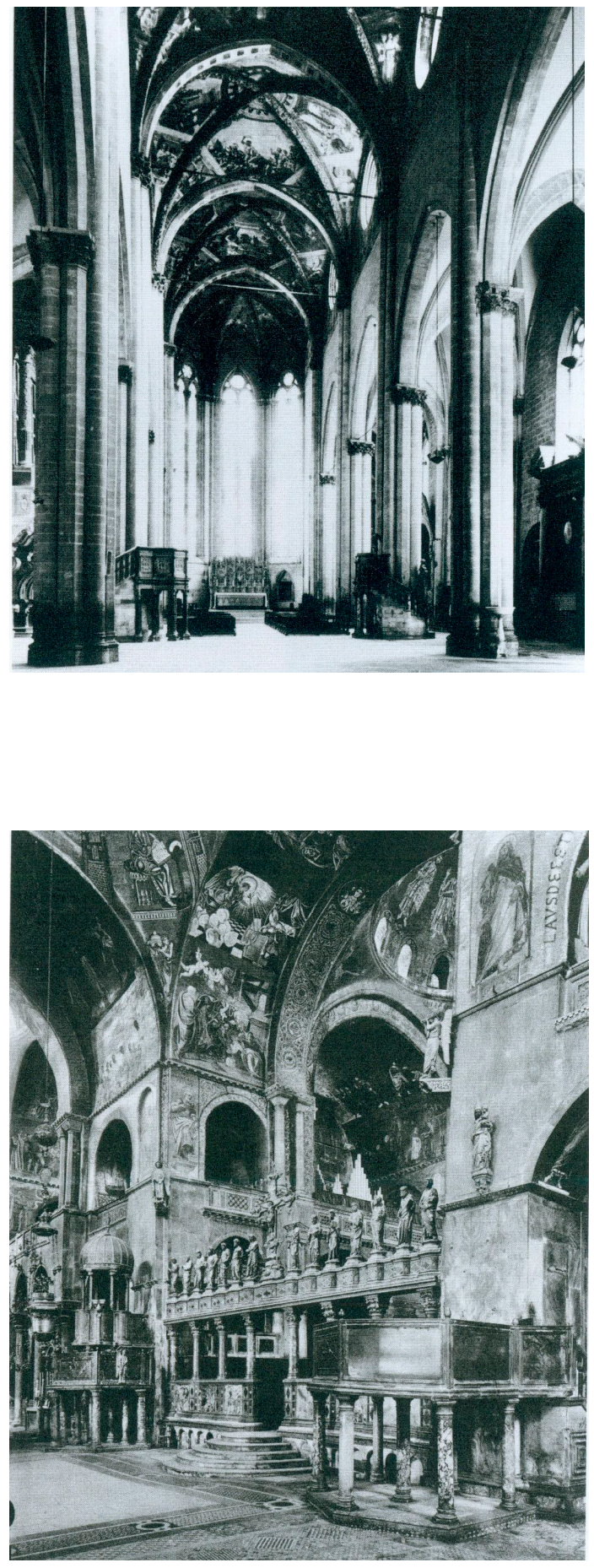

Fig.1 - General View, Arezzo, Cathedral (Alinari)
Fig.2 - General View, Venice, San Marco (Alinari) 
Fig.3 - General View, Modena, Cathedral (Alinari)

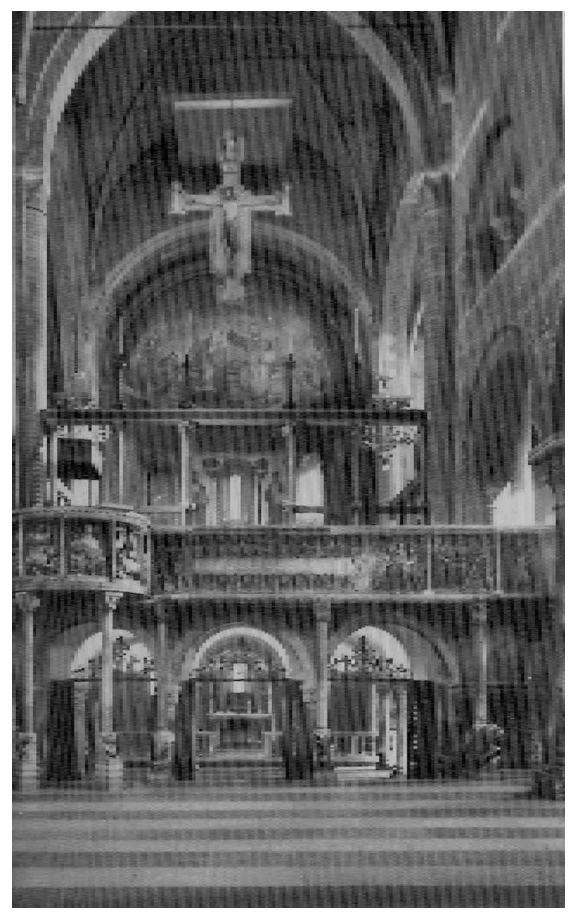

Fig.4 - General View, Milan, Cathedral (Alinari)






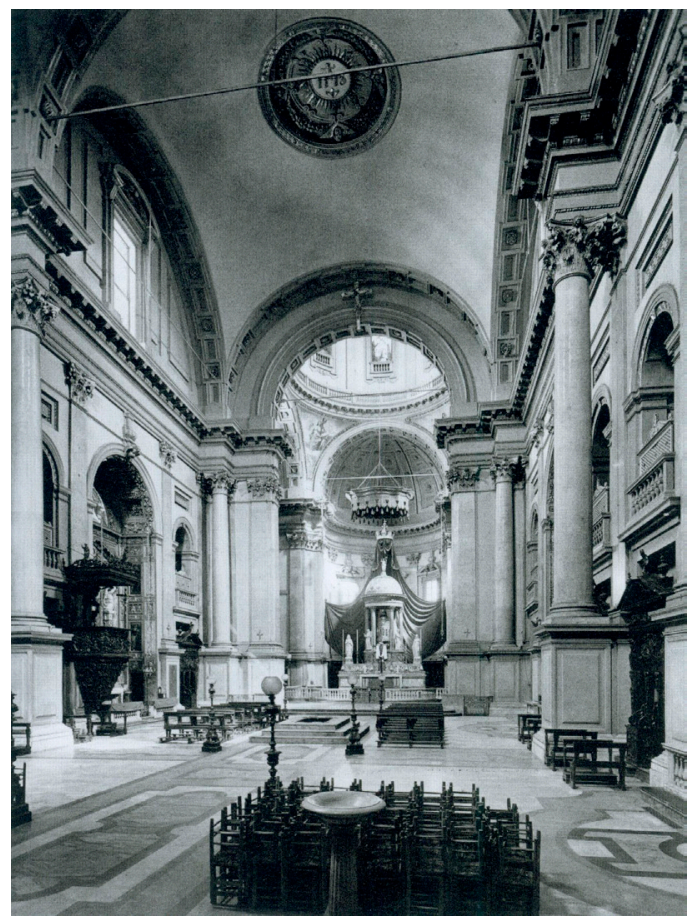

Fig.5 - General View, San Fedele, Cathedral (Alinari) 